\title{
The Cost of Harmony
}

\author{
Barry Bracewell-Milnes, Banstead, England
}

The intergovernmental agreement of the European Union constitution at the end of June purports to leave the pre-existing elements of fiscal sovereignty with the Member States. However, in practice fiscal sovereignty remains under threat. In December 1998, M. YvesThibault de Silguy, as European Commissioner for Economic Affairs, said: 'We must harmonize taxes .... harmonization of corporate taxes is the next item on the agenda'. In June, France and Germany secured the agreement of the Netherlands to press for a minimum EU rate of corporation tax. And under Article III-70 of the draft constitution 'Member States shall conduct their economic policies in order to contribute to the achievement of the Union's objectives', which leaves it open to the European Court of Justice to require measures of tax harmonization for this purpose.

Tax harmonization doesn't come free of cost. By comparison with the no-tax situation, tax imposes three sets of distortions: first, those within a unitary state; second, those between Member States of entities like the European Union; third, those between such entities and the rest of the world. Even in a unitary state, taxation can damage the economy by making leisure artificially attractive by comparison with work and spending artificially attractive by comparison with saving. A high-tax Fortress Europe that succeeded in eliminating the second of these three types of distortion might do more harm than good by simultaneously increasing the first and the third. Distortions of the third type can be eliminated only by a system of universal and compulsory world government, a project with abundant disadvantages of its own.

At a less economic and more philosophical level, diversity has its own merits. Tennyson wrote in Morte d'Arthur

\section{And God fulfils Himself in many ways \\ Lest one good custom should corrupt the world.}

And the musical metaphor of harmonization indicates, not unison, but the compatibility of divergent voices; in fiscal terms, the competition of sovereign jurisdictions, from which the best system has a chance of emerging.

For institutional reasons including the increasing importance of pressure groups, the tax burden in modern democracies tends to rise irrespective of the merits of the government spending that the taxes support. The burden has generally grown heavier throughout the EU and the OECD since the present series of figures began in 1965. It is telling that Margaret Thatcher, with the creed and reputation of a tax cutter, left the tax burden as heavy at the end of her period of office as it had been at the beginning; her achievement was to prevent it from rising. France is the most heavily taxed country according to Forbes Global's tax index, with Belgium second and Sweden third. The United Kingdom comes twenty-sixth although it is catching up (42 per cent of gross domestic product or over 47 per cent of national income, and rising). Ireland is thirty-ninth, and some of the new entrants to the EU have low or zero rates of corporation tax. These countries are coming under pressure to raise taxes from Germany, Sweden and elsewhere. High-tax countries harm only themselves, whereas low-tax countries have a competitive advantage and are accused of tax dumping. These patterns of thought find expression in the institutions of the EU. VAT can be increased but not reduced. We are fortunate that the Commission's mid-1970s proposal to harmonize corporation tax rates within the range 45 per cent to 55 per cent was not accepted; if it had been, the reductions in corporation tax rates over the last two decades would not have been possible.

Tax competition reduces tax rates and tax burdens and is thus opposed by those, inside and outside government, who wish to keep taxation high. 'Harmful' tax competition, which attacks high-tax jurisdictions and shifts the pattern of activity, is harmful to the losing governments and beneficial to the taxpayer, just as competition between supermarkets is harmful to the losing supermarket and beneficial to the consumer. In the Soviet Union, the black economy was a lifeline to economic survival and was recognized as such by the political elite, who knew that they would not be able to get their cars serviced through official channels. The black economy can likewise be a lifeline in the EU and throughout the West, enabling productive activity to take place which would be suppressed and driven out by the full rigour of tax law. Tax competition mitigates and relaxes this rigour and serves to bring activities out of the black economy and into the white.

Tax competition is particularly desirable in the area of capital taxation (inheritance tax, capital gains tax, stamp duty), where present practice varies widely and competition gives the better system the chance of ousting the worse.

The 1998 OECD initiative against tax avoidance and tax competition targets (among taxpayers and 
their activities) beneficial ownership of companies, beneficiaries of trusts and bearer shares. OECD countries that have resisted include Luxembourg and Switzerland. Singapore is a major threat to the project. Other countries that have resisted at various stages include Andorra, British Virgin Islands, Cayman Islands, Liechtenstein, Monaco, Montserrat. Seven countries have refused so far to cooperate with the Financial Action Task Force - Cook Islands, Guatemala, Indonesia, Myanmar, Nauru, Nigeria, Philippines. Several of these are important jurisdictions. The phrase the last man standing indicates that a single recalcitrant can bring down a tax cartel or any other cartel and that the advantages of recusancy are maximized for the last man standing. The success of the OECD tax cartel is by no means assured. The campaign against low-tax and mid-tax jurisdictions has already been abandoned as a result of an initiative by the United States in 2000.

The example of Hong Kong shows that a single small competitive jurisdiction can prosper in a protectionist environment by unilaterally abandoning protection and opening its borders to imports. The same principle holds good for tax competition against tax protection and tax harmony. The cost of harmony is being left behind by the competition. 